\title{
The Effect of Land Cover Change on Flooding in Texas
}

\author{
Seong Nam Hwang \\ Environmental Science Program, Department of Biology, Southeast Missouri State University, Cape Girardeau, \\ MO, USA \\ Email:shwang@semo.edu
}

How to cite this paper: Hwang, S.N. (2017) The Effect of Land Cover Change on Flooding in Texas. Journal of Geoscience and Environment Protection, 5, 123-137. https://doi.org/10.4236/gep.2017.59009

Received: July 29, 2017

Accepted: September 3, 2017

Published: September 6, 2017

Copyright (c) 2017 by author and Scientific Research Publishing Inc. This work is licensed under the Creative Commons Attribution International License (CC BY 4.0).

http://creativecommons.org/licenses/by/4.0/

\section{(c) (i) Open Access}

\begin{abstract}
The world population has been increasing while, similarly, both the number of environmental disasters and the loss resulting from those have been on the rise. It is also expected that the trend will continue. Especially, what is noticeable is that more and more people and property concentrate on cities. In fact, urbanization is a major global trend simply because most people want to get their jobs, raise and educate their children, and enjoy riches of diverse cultures, recreation activities, and entertainment, which cities can provide to them. Urbanization always involves transforming the natural environment into a man-made environment, contributing to changes in land use and land cover patterns as well as in landscape and hydrology in the built-up areas. These changes, in turn, negatively influence the natural environment because those changes almost always tend to result in the disruption of its fragile ecosystems in balance. In addition, the changes mean the land used, for example, for a natural ecosystem may be converted into an impervious land, which can increase human vulnerability to floods, causing human and property losses. There has been some research done to investigate the relationship between land use/land cover change and environmental hazards. However, little research has been conducted to test direct effects of land cover change on environmental disasters such as floods, hurricanes, and hazardous material releases by using GIS and remote sensing technologies. Therefore, this research aimed to analyze the effect of land cover change on floods. More specifically, the research tested whether land cover change is related to flood disasters in Texas from 1993 to 2012. One of the main findings of this research is that both decrease in forest areas and increase in urban built-up areas contributed to the property damage resulting from flood events.
\end{abstract}

\section{Keywords}

Disaster Mitigation, Environmental Hazard, Land Use Change, Emergency 
Management, Disaster Planning, Flooding

\section{Introduction}

It is apparent that the number of environmental disasters and the human and property loss resulting from them have been on the rise in the recent decade due to the fact that urban centers get more and more densely developed while human populations and property are highly concentrated in areas physically vulnerable to natural and technological hazards. In particular, human vulnerability to floods is one of the major natural hazards leading to damage and loss of life when it occurs. According to Federal Emergency Management Agency [1], approximately 17,000 communities are situated in the areas which are at risk of flooding while about 9.6 million households and property worth $\$ 390$ billion face a flood hazard that is characterized by a high probability or that has a $1 \%$ chance of occurring per year; however, only $20 \%$ to $30 \%$ of building at risk is said to be covered by flood insurance.

Since the Industrial revolution, human populations all across the world have been increasing and will continue to do so in the future. Especially, the increase of the population is generally happening in our urban environment, meaning that more and more people and property concentrate on cities. Urbanization is a major global trend simply because people want to get their jobs, raise their children, and live their lives in cities. As urbanization always transforms the natural environment into a man-made one, attracting people and materials, thus contributing to change not only in land use and land cover but also landscape and hydrological systems in that area. This change, in turn, negatively influences the natural environment, which can lead to an increase in disasters and crises as well as vulnerability. For example, changing a certain floodplain into a built-up area used to develop a subdivision neighborhood makes that particular area and adjacent ones less permeable to precipitation and more vulnerable to flooding. As a result, a heavy rain, for example, can flood those areas, claiming loss of lives and property.

There has been some research done to investigate relationships between land use/land cover change and environmental hazards [2] [3] [4] [5] [6]. However, little research has been conducted to test the direct effects of land cover change on environmental disasters such as floods, hurricanes, hazardous material releases. Therefore, this research aims to analyze the effect of land cover change on environmental hazards by using GIS and remote sensing technologies. More specifically, its main goal is to test whether land cover change is related to floods in the state of Texas from 1993 to 2012 by using such technologies. The reason why the time frame (i.e., 1993 to 2012) was chosen is the remote sensing data obtained from the National Land Cover Database (NLCD) were available only for the time period when this research was conducted.

This research aims to analyze the effect of land cover change in the state of 
Texas on environmental disasters (i.e., flooding). To do so, property damage caused by floods was used as a proxy to environmental disasters. More specifically, the goal of the research is to test whether land cover change is related to a flood disaster in Texas from 1993 to 2012.

To achieve the objective, two research hypotheses were developed. The main point of the hypotheses is that the increase in the spatial extent of built environment and the decrease in that of the natural environment contribute to the increase of loss of life and property resulting from flooding events. These hypotheses and their rationales are as follows:

- Hypothesis 1: The change in forest area within a county from 1992 to 2012 is correlated with its total property damage resulting from flooding.

- Rationale for Hypothesis 1: Forest area can contain much precipitation through an infiltration process instead of letting the runoff flow into the urban built environment, rivers or lakes during rainfall because the area is pervious. However, if forest area is converted into impervious built-up area, then flooding is more likely to happen than ever. Therefore, the decrease in spatial extent of forest is expected to contribute to flooding, which can claim loss of life and property damage, especially in the urban areas.

- Hypothesis 2: The change in built-up area within a county from 1992 to 2012 is correlated with its total property damage resulting from flooding.

- Rationale for Hypothesis 2: Impervious areas that comprise built-up sites (e.g., buildings, roads, streets, and parking lots) make runoff stay longer mostly in the roads and streets, which causes the water flow level to increase in urban areas, resulting in flooding. Therefore, the increase in spatial extent of built-up area is expected to contribute to flooding, which is highly likely to claim greater loss of life and property damage.

\section{Materials and Methods}

\subsection{Study Area and Data}

\subsubsection{Study Area}

The study area is the state of Texas. The state is situated in the south central part of the country and bordered by Louisiana on the east, Oklahoma on the north, New Mexico on the west, and the Gulf of Mexico and Mexico on the south. This second largest state in terms of its population (about 25.7 million in 2011) [7] and spatial extent (268,820 square miles) has three metropolitan areas such as Houston, Dallas-Fort Worth, and San Antonio. The year 2010 United Census statistics show that the state's racial and ethnicity consist of White $(70.4 \%$; Non-Hispanic Whites: 45.3\%), Black or African American (11.8\%), Native American (0.7\%), Asian (3.8\%), and Pacific Islander (0.1\%) with other race (10.5\%) [8]. Much of Texas has been plagued with various natural (e.g., floods, hurricane, tornadoes, wildfire, and extreme weather) and technological disasters (e.g., hazardous material releases). Since the state has Tornado Alley along its northern region, the most tornadoes occur in this state every year. Hurricanes 
are also one of the salient natural events in this state. A hurricane which struck Galveston in 1900 in the southern part of Texas claimed over 8000 deaths, which ranked the first in the most death tolls in the U.S. history [9]. Also, the state has a high risk from hazardous material accidents because the state has a large number of oil refining and manufacturing facilities along the coast line [10]. If a hurricane of category 3, 4 or 5 hit oil-gas facilities located in the east coast, the very deadliest and costliest extreme disaster would happen in the country. In addition, Texas has seen a lot of flooding events. According to National Weather Service, it is floods and flash floods that claim an average of 15 causalities every year in Texas. Especially, flash floods with little or no lead time for emergency warnings rapidly trigger runoff, which can lead to more damage and loss of life than regular floods that usually happen within or near floodplains.

As mentioned earlier, the economic damages triggered by these natural and technological disasters in the state are likely to increase as a consequence of population growth and its concentration, especially in fifteen counties along the Gulf coast region. In reality, according to the Census Bureau data, 10 out of 13 counties in the Gulf coast region have experienced rapid population growth rates from 2000 to 2008 , ranging from $10 \%$ to $50 \%$. Additionally, it is more important to note that this increased physical vulnerability is likely to be related to land cover change over the last decade. This issue will be dealt with in details in the section of research results.

\subsubsection{Data}

One of the main datasets used for this research is the National Land Cover Database (NLCD), which can publicly be downloaded from

http://www.mrlc.gov/index.php. NLCD is Lansat TM-based land cover maps of the United States. Landsat TM sensor produces seven spectral bands of imagery, each of which has a spatial resolution of 30 meters, and one far-infrared band of imagery, which has a spatial resolution of 120 meters. These remote sensing images can be downloaded at no charge from the USGS Earth Explorer website (http://earthexplorer.usgs.gov).

NLCD products currently available include land cover maps for 1992, 2001, and 2006, and land cover change between 1992 and 2001, all of which have metadata including spatial reference and land cover classification systems. These datasets were developed by the Multi-Resolution Land Characteristics Consortium (MRLC) consisting of a host of federal government agencies. MRLC is a partnership to conduct a national land cover mapping project. In 1992 participants of MRLC included the Environmental Protection Agency, the United States Geologic Survey, National Oceanic and Atmospheric Administration, the United States Forest Service, the National Aeronautics and Space Administration, and the Bureau of Land Management while the list of 2001 and 2006 was added to the list of the 1992 participants, which include LANDFIRE, the Natural Resources Conservation Service, the National Park Service, the US Fish and Wildlife Service, and the Office of Surface Mining. 
In 1992, MRLC partners started to develop the first land-cover data, the NLCD 1992 for the continuous 48 United States by using 30-meter Landsat TM images which were obtained in 1991, 1992 and 1993 [11]. This land cover map consists of 21 different classes of land cover. In 2006, MRLC began conducting a third-time land-cover mapping project. This land cover classes follows the land cover classification method used in 2001, which features 16 different classes. All the different land classes are shown in Table 1 below.

Even though the 1992 and 2006 NLCD vary with classification methods, this research used only the classes found in both NLCDs (e.g., open water, forest, and wetlands). In addition, some classes were merged so that each NLCD could have

Table 1. NLCD classification schemes [12].

\begin{tabular}{|c|c|}
\hline 1992 Scheme & 2001-2006 Scheme \\
\hline 11-Open water & 11-Open water \\
\hline 12-Perennial Ice/Snow & 12-Perennial Ice/Snow \\
\hline $\begin{array}{l}\text { 21-Low Intensity Residential } \\
\text { 22-High Intensity Residential } \\
\text { 23-Commercial/Industrial/Transportation }\end{array}$ & $\begin{array}{l}\text { 21-Developed, Open Space } \\
\text { 22-Developed, Low Intensity } \\
\text { 23-Developed, Medium Intensity } \\
\text { 24-Developed, High Intensity }\end{array}$ \\
\hline $\begin{array}{l}\text { 31-Bare Rock/Sand/Clay } \\
\text { 32-Quarries/Strip Mines/Gravel Pits } \\
\text { 33-Transitional }\end{array}$ & $\begin{array}{l}\text { 31-Barren Land } \\
\text { 32-Unconsolidated Shore }\end{array}$ \\
\hline $\begin{array}{l}\text { 41-Deciduous Forest } \\
\text { 42-Evergreen Forest } \\
\text { 43-Mixed Forest }\end{array}$ & $\begin{array}{l}\text { 41-Deciduous Forest } \\
\text { 42-Evergreen Forest } \\
\text { 43-Mixed Forest }\end{array}$ \\
\hline 51-Shrubland & $\begin{array}{l}\text { 51-Dwarf Scrub } \\
52-\text { Scrub/Shrub }\end{array}$ \\
\hline 61-Orchards/Vineyards/Other & \\
\hline 71-Grassland/Herbaceous & $\begin{array}{l}\text { 71-Grassland/Herbaceous } \\
\text { 72-Sedge Herbaceous } \\
\text { 73-Lichens } \\
\text { 74-Moss }\end{array}$ \\
\hline $\begin{array}{l}\text { 81-Pasture/Hay } \\
\text { 82-Row Crops } \\
\text { 83-Small Grains } \\
\text { 84-Fallow } \\
\text { 85-Urban/Recreational Grasses }\end{array}$ & $\begin{array}{l}\text { 81-Pasture/Hay } \\
\text { 82-Cultivated Crops }\end{array}$ \\
\hline $\begin{array}{l}\text { 91-Woody Wetlands } \\
\text { 92-Emergent Herbaceous Wetlands }\end{array}$ & $\begin{array}{l}\text { 90-Woody Wetlands } \\
\text { 91-Palustrine Forested Wetland } \\
\text { 92-Palustrine Scrub/Shrub } \\
\text { 93-Estuarine Forested Wetlands }{ }^{1} \\
\text { 94-Estuarine Scrub/Shrub } \\
\text { 95-Emergent Herbaceous Wetland } \\
\text { 96-Palustrine Emergent Wetland (Persistent) }{ }^{1} \\
\text { 97-Palustrine Emergent Wetland }{ }^{1} \\
\text { 98-Palustrine Aquatic Bed }{ }^{1} \\
\text { 99-Estuarine Aquatic Bed }\end{array}$ \\
\hline
\end{tabular}

${ }^{1}$ C-CAP (Coastal Change Analysis Program) only; ${ }^{2}$ Alaska only. 
the same class. For example, Class No. 21 to 23 in NLCD 1992 and Class No. 21 to 24 in NLCD 2006 were combined respectively to form a new common class, called the built-up area.

The 1992 land cover map was made in 2001 by 1) producing mosaicked scenes and clusters based on an unsupervised algorithm, 2) defining classes based on aerial photos, and 3) reclassifying some complicated clusters by using an ancillary data [13]. Meanwhile, NLCD 2006 that followed NLCD 2001 was made by using the fundamental model initiated by the NOAA C-CAP (The Coastal Change Analysis Program). C-CAP aims to create a nationwide standardized database that contains information on land cover and land change across the coastal areas. NLCD 2001 and 2006 have been improved, compared with NLCD 1992; While NLCD 1992 was a dataset for the national land cover, NLCD 2001 and 2006 are made up of three components: "land cover, impervious surface and canopy density" [14].

The other main dataset used for this research is flood loss data derived from Storm Events Database, developed and maintained by NOAA's National Climatic Data Center (NCDC). This data archive, which is freely available to the public (http://www.ncdc.noaa.gov/stormevents), provides information on an array of records for storm events (i.e., floods, flash floods, hails, hurricanes, high wind, and extreme weather) at the city or town level, ranging from 1950s to 2012. This database also provides information on the number of injuries and deaths and the estimated amount of property damages for each event by city or town. For this research purpose, records related to flooding for the state of Texas from 1992 to 2012 were extracted from all the records for the nation.

\subsection{Analytical Methods}

The main goal of this research is to investigate the effect of land cover change in Texas on environmental disasters (i.e., flooding). In doing so, the loss of life and property caused by flooding will be used as a proxy to disasters. The research hypothesis is that the increase in the spatial extent of the built environment and the decrease in that of the natural environment will be related to the increase of loss of life and property resulting from flooding events. Therefore, it was of much essence to delineate the land cover change for each class in terms of spatial extent by county.

Since the study area is the state of Texas, the 1992 and 2006 land cover maps covering only the study area were extracted out of each of the 1992 and 2006 NLCDs covering all the lower 48 states by using a function, called "Create New File" on the ENVI program. Then, both the land cover maps and Texas County boundary map were added into the ArcMap program, on which the spatial extent for each of the land cover classes by county was respectively calculated by using an Arctool, called "Tabulate Area" within an extension of "Spatial Analyst".

Once these two types of datasets (i.e., 1992 and 2006 NLCD, and flood loss data) are gathered, both descriptive statistics using graphs and charts and infe- 
rential statistics using correlation analyses will be conducted to test whether land cover change is associated with environmental disasters. The results will be displayed on GIS maps to clearly show the relationships between those variables.

\subsection{NLCD Land Cover Maps}

Two land cover class maps were developed from NLCDs of 1992 and 2006. Each of the maps had the same 7 classes, because several classes with similar characteristics were combined into a common class. The following land classes were merged: Low Intensity Residential, High Intensity Residential, and Commercial/Industrial/Transportation from the 1992 NLCD were converted into a common class named Built-up while similarly, Developed Open Space, Low Intensity, Medium Intensity, High Intensity from the 2006 NLCD were converted into the Built-up class as well; Orchards/Vineyards/Other, Grassland/ Herbaceous, Pasture/Hay, Row Crops, Small Grains, Fallow, and Urban/Recreational Grasses from the 1992 NLCD were merged into a common class named Grass while Grassland/Herbaceous, Sedge Herbaceous, Lichens, and Moss from the 2006 NLCD were merged into the Grass class.

Figure 1 shows the land cover maps of Texas, developed from the NLCDs of 1992 and 2006, which were classified as 7 different classes; Water, Built-up, Bare Land, Forest, Shrub, Grass, and Wetland. Comparing these two maps, it is notable that during this period, the spatial extents in three metropolitan areas (i.e., Dallas-Fort Worth, San Antonio-New Braunfels, and Houston) in red collar, which indicates the Built-up class, have all increased. Also, the spatial extent for the Built-up class has also increased within many other small cities, which were distributed all across the state of Texas. It is also important to notice that the spatial extent for the Forest class mainly situated in the middle and eastern part in the state dramatically decreased over the same period. These results suggest that some part of the forest areas has been changed into an urban built-up area.

Table 2 illustrates descriptive statistics for land cover change at the state level. Since this research focuses on analyzing the relationships between the Built-up area and the Forest area, the description of the other variables such as the areas for Grass, Shrub, Wetland, and Water will be omitted. In addition, the unit of

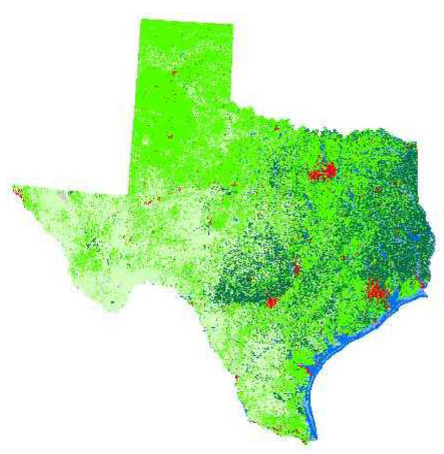

Year 1992

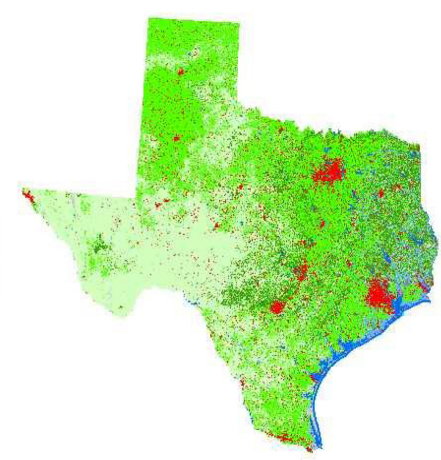

Year 2006

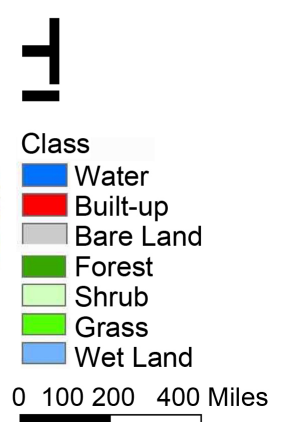

100200400 Miles

Figure 1. Land cover maps of texas. 
Table 2. Descriptive statistics for land cover change.

\begin{tabular}{cccccc}
\hline Class & \multicolumn{1}{c}{$\begin{array}{c}2006 \\
\text { Total }\end{array}$} & \multicolumn{2}{c}{ Total } & $\begin{array}{c}\mathrm{D}^{*} \\
(\%)\end{array}$ \\
\cline { 2 - 5 } & $\mathrm{m}^{2}$ & $\%$ & $\mathrm{~m}^{2}$ & $\%$ & \\
\hline Water & $19,346,676,300$ & 3 & $16,185,410,100$ & 2 & -1 \\
Built-up & $13,096,528,200$ & 2 & $43,257,759,300$ & 6 & 4 \\
Bare Land & $8,540,986,500$ & 1 & $4,361,076,000$ & 1 & 0 \\
Forest & $110,883,012,300$ & 15 & $70,185,145,500$ & 10 & -5 \\
Shrub & $225,466,770,600$ & 31 & $273,687,414,300$ & 39 & 8 \\
Grass & $341,246,325,600$ & 47 & $259,642,178,100$ & 37 & -10 \\
Wetland & $14,019,094,800$ & 2 & $28,182,092,400$ & 4 & 2 \\
Total & $732,599,394,300$ & 100 & $695,501,075,700$ & 100 & \\
\hline
\end{tabular}

$\mathrm{D}^{*}$ : Difference.

the analysis for this table is at the state level, a descriptive analysis at the county level will not be discussed.

One of the main reasons for the big difference between 1992 and 2006 in the total spatial extent of the entire Texas state is due to the fact that the land area of non-classified sites was excluded in calculating the total spatial extent of Texas in this table. As seen in Table 1, in the 1992 land cover map, the site which was classified as Grass accounted for $47 \%$ of the total spatial area of Texas, followed by Shrub (31\%) and Forest (15\%) while each percentage of the sites classified as Bare Land, Built-up, Wetland, and Water ranged only from $1 \%$ to $3 \%$. Meanwhile, in the 2006 land cover map, the site classified as Shrub accounted for 39\% of the total area, followed by Grass (37\%) and Forest (10\%) while each percentage of the sites classified as Bare Land, Built-up, Wetland, and Water ranged only from $1 \%$ to $4 \%$.

It is noticeable that the Built-up area increased from $2 \%$ to $4 \%$ over the period of 1992 and 2006 while the Forest area decreased from 15\% to 10\%. In addition, a big increase in the Shrub class and a big decrease in the Grass class might have been influenced by the classification definition; namely, the land cover classifications for Shrub and Grass in the 1992 NLCD were significantly different from those in the 2006 NLCD. It is of much interest that the site classified as Wetland increased from $2 \%$ to $4 \%$. The first reason is that the classification method for the Wetland differed between the 1992 NLCD and the 2006 NLCD. In other words, the classes converted into the Wetland class in the 1992 NLCD for this research purpose include two different classes (Woody Wetlands and Emergent Herbaceous Wetlands) while the classes converted into the Wetland class in the 2006 NLCD include 10 different classes (Woody Wetlands, Palustrine Forested Wetland, Palustrine Scrub/Shrub, Estuarine Forested Wetlands, Estuarine Scrub/ Shrub, Emergent Herbaceous Wetland, Palustrine Emergent Wetland, Palustrine Emergent Wetland, Palustrine Aquatic Bed, and Estuarine Aquatic Bed). The second reason is that the increase in the Wetland class in year 2006 could be influenced by a seasonal factor. For example, some counties located in the area 
vulnerable to hurricanes and floods may have experienced these types of extreme events at the time when the remote sensor took the image. This may have contributed to the rise of the Wetland spatial extent area.

To show how much land cover change in terms for urban built-up area occurred, top ten counties were chosen. As shown in Figure 2, these counties had a big increase in the spatial extent for Built-up area from 1992 to 2012. It is important to note that counties with metropolitan areas-Harris (including Houston), Dallas (including Dallas), Tarrant (including Fort Worth and Arlington), Bexar (including San Antonio) and Travis (including Austin, the capital of the state)-continue to experience fast-growing urbanization in the State. More specifically, Harris County and Dallas County ranked in the fifth and ninth respectively in terms of population in the United States are still expanding their own built-up environment by consuming natural environment such as green vegetation, and forest areas.

Meanwhile, Figure 3 shows top ten counties which had a big decrease in the

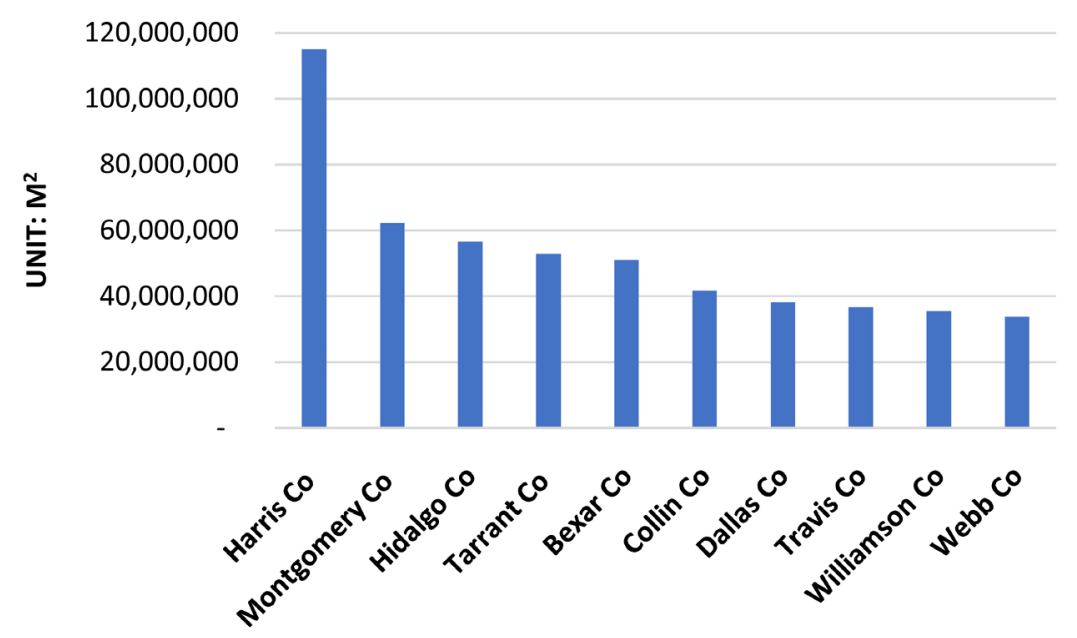

Figure 2. Top 10 counties with an increase in built-up area (1992-2012).

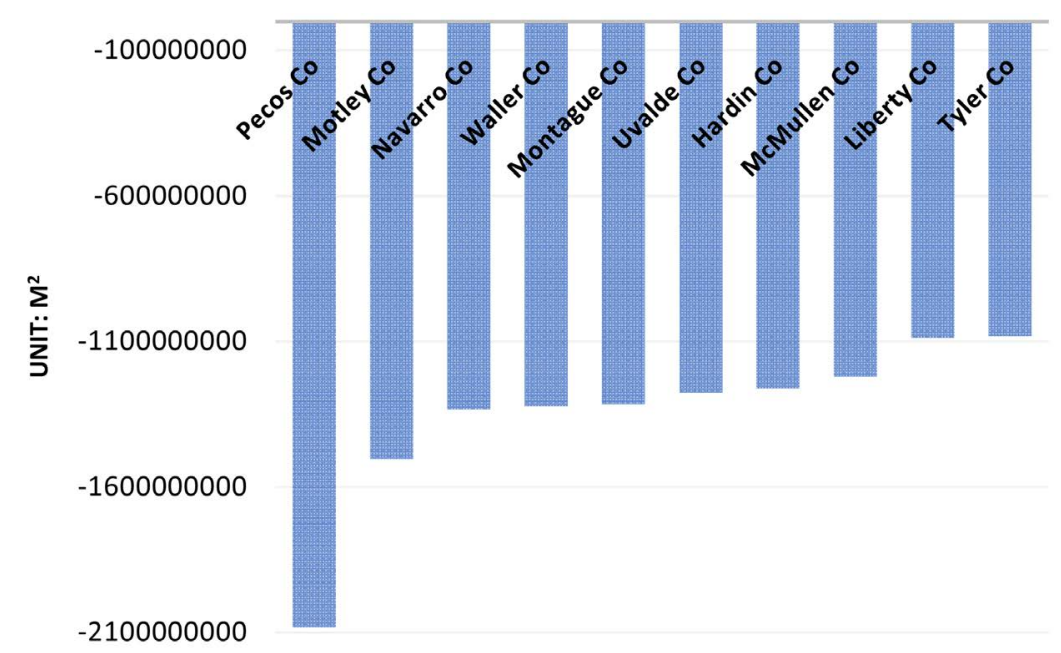

Figure 3. Top 10 counties with a decrease in forest area (1992-2012). 
spatial extent for the Forest class from 1992 to 2012. What should be noted is that the counties' population is relatively smaller than that of the top ten counties listed in Figure 2. The fact that the forest area within these counties is converting into area for other urban land use purposes tells us that their urban built-up area is on the rise simply because the forest land is usually being developed into built environment. This means that small cities in the state of Texas are likely to be newly developing and growing into big cities. It also means that deforestation within these counties can make flooding events more frequent than ever.

\subsection{Flood Loss Map}

To investigate the relationship between land cover change and environmental disasters (i.e., floods), the data related to flooding were required. Therefore, flood loss data for the state of Texas were derived from the Storm Events Database administered by NOAA's National Climatic Data Center (NCDC). Since this database contains information on a variety of records for storm events such as floods, hurricanes, tornadoes, and extreme weather, only the records related to flooding for Texas from 1992 to 2012 were extracted from all the records of the nation.

For example, from 1993 to 2007, Texas experienced about 9800 flood events in 209 counties among 254 counties. These events caused an estimated \$148 million in economic loss, 257 fatalities and 6927 injuries. Based upon the estimated property damage caused from 1993 to 2007, a flood loss map was developed to show a huge increase in property damage during the period. Figure 4 clearly shows an increase in property damage appears chiefly in a north-central-south belt in the central and eastern region of Texas, even though such increase does appear in its northwestern region. Especially, this damage increase is mainly seen in the counties including Harris, Dallas, Tarrant, Bexar, and Travis.

\section{Results}

Two types of datasets (i.e., both the 1992 NLCD and 2006 NLCD, and flood loss data) were put into the spreadsheet in the SPSS program for correlational analysis, which showed whether or not the land cover change over time was correlated to environmental disasters. Table 3 shows all the correlations results. In these correlations, all the land cover types and the total property damage (which happened from 1993 to 2012) were compared. The correlation results showed that the land cover types-Water, Bareland, Shrub, and Grass-were not correlated with the property damage. However, the results showed that both Built-up area $\left(0.638^{\star *}\right)$ and Wetland area $\left(0.203^{* *}\right)$ were positively related to its total property damage resulting from flooding. Meanwhile, the statistical analysis also showed that Forest area $\left(-0.112^{\star}\right)$ was negatively correlated with its total property damage resulting from flooding. As discussed in the research hypotheses above, it is reasonable that there is a positive correlation (i.e., the increase in the Built-up 


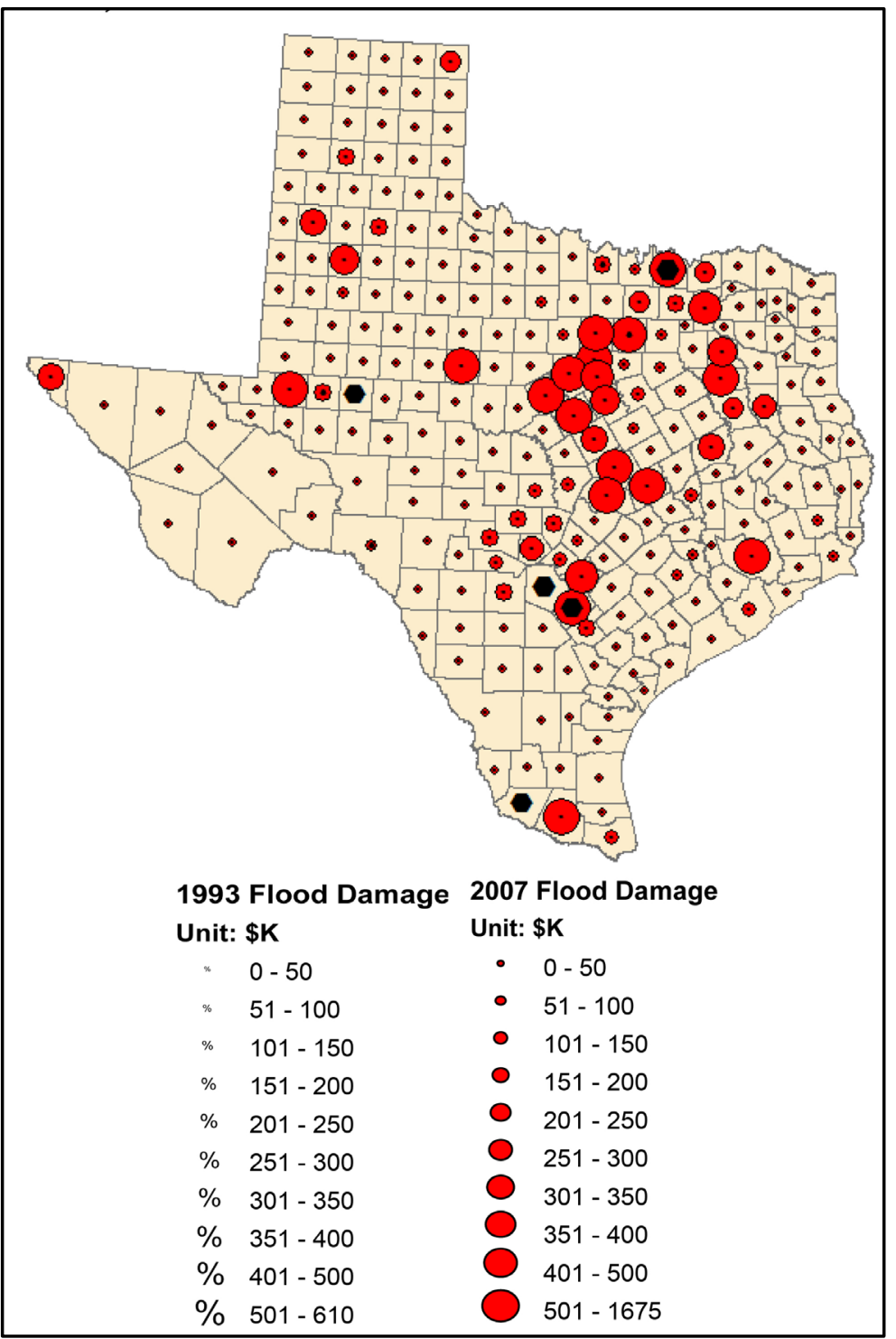

Figure 4. Flood loss map of texas (1993 and 2007).

area versus the increase in property damage, and a negative correlation (i.e., the decrease in the Forest area and the increase in property damage). However, the reason why there is an association between the increase in the Wetland area and the increase in the property damage remains unknown. As mentioned above, the increase in the spatial extent for Wetland area may have been affected by a hurricane occurring in the state of Texas or may have been due to the classification definition. In fact, the original classification methods for the Wetland clearly varied between the 1992 NLCD and 2006 NLCD. Therefore, some errors may have been introduced in merging some classes into a common Wetland class.

\section{Discussion and Conclusions}

Almost all the countries in the world have seen that urbanization has been, and it will continue to be a trend. It is very important to note that this urbanization 
Table 3. Correlation results of land cover variables and property damage from flooding.

\begin{tabular}{|c|c|c|c|c|c|c|c|c|c|}
\hline \multicolumn{2}{|c|}{ Classification } & Water & Built-up & $\begin{array}{l}\text { Bare } \\
\text { Land }\end{array}$ & Forest & Shrub & Grass & $\begin{array}{l}\text { Wet } \\
\text { Land }\end{array}$ & $\begin{array}{c}\text { Total } \\
\text { Property } \\
\text { Damage }\end{array}$ \\
\hline \multirow{3}{*}{ Water } & $\begin{array}{c}\text { Pearson } \\
\text { Correlation }\end{array}$ & 1 & $0.148^{* *}$ & $-0.154^{\star \star}$ & 0.076 & $-0.122^{\star}$ & 0.031 & $0.106^{\star}$ & 0.07 \\
\hline & $\begin{array}{c}\text { Sig. } \\
\text { (1-tailed) }\end{array}$ & & 0.009 & 0.007 & 0.115 & 0.026 & 0.31 & 0.046 & 0.134 \\
\hline & $\mathrm{N}$ & 254 & 254 & 254 & 254 & 254 & 254 & 254 & 254 \\
\hline \multirow{3}{*}{ Built-up } & $\begin{array}{c}\text { Pearson } \\
\text { Correlation }\end{array}$ & $0.148^{\star *}$ & 1 & 0.057 & -0.021 & $-0.129^{*}$ & 0.036 & $0.195^{\star *}$ & $0.638^{* *}$ \\
\hline & $\begin{array}{c}\text { Sig. } \\
\text { (1-tailed) }\end{array}$ & 0.009 & & 0.184 & 0.37 & 0.02 & 0.282 & 0.001 & 0 \\
\hline & $\mathrm{N}$ & 254 & 254 & 254 & 254 & 254 & 254 & 254 & 254 \\
\hline \multirow{3}{*}{$\begin{array}{l}\text { Bare } \\
\text { Land }\end{array}$} & $\begin{array}{l}\text { Pearson } \\
\text { Correlation }\end{array}$ & $-0.154^{\star *}$ & 0.057 & 1 & $0.120^{*}$ & 0.089 & $0.120^{*}$ & -0.098 & -0.019 \\
\hline & $\begin{array}{c}\text { Sig. } \\
\text { (1-tailed) }\end{array}$ & 0.007 & 0.184 & & 0.028 & 0.079 & 0.028 & 0.06 & 0.382 \\
\hline & $\mathrm{N}$ & 254 & 254 & 254 & 254 & 254 & 254 & 254 & 254 \\
\hline \multirow{3}{*}{ Forest } & $\begin{array}{l}\text { Pearson } \\
\text { Correlation }\end{array}$ & 0.076 & -0.021 & $0.120^{*}$ & 1 & $-0.256^{* *}$ & $-0.213^{\star *}$ & -0.051 & $-0.112^{\star}$ \\
\hline & $\begin{array}{c}\text { Sig. } \\
\text { (1-tailed) }\end{array}$ & 0.115 & 0.37 & 0.028 & & 0 & 0 & 0.208 & 0.038 \\
\hline & $\mathrm{N}$ & 254 & 254 & 254 & 254 & 254 & 254 & 254 & 254 \\
\hline \multirow{3}{*}{ Shrub } & $\begin{array}{l}\text { Pearson } \\
\text { Correlation }\end{array}$ & $-0.122^{*}$ & $-0.129^{\star}$ & 0.089 & $-0.256^{\star *}$ & 1 & -0.041 & $-0.115^{\star}$ & -0.055 \\
\hline & $\begin{array}{c}\text { Sig. } \\
\text { (1-tailed) }\end{array}$ & 0.026 & 0.02 & 0.079 & 0 & & 0.256 & 0.033 & 0.19 \\
\hline & $\mathrm{N}$ & 254 & 254 & 254 & 254 & 254 & 254 & 254 & 254 \\
\hline \multirow{3}{*}{ Grass } & $\begin{array}{l}\text { Pearson } \\
\text { Correlation }\end{array}$ & 0.031 & 0.036 & $0.120^{*}$ & $-0.213^{\star *}$ & -0.041 & 1 & -0.096 & 0.022 \\
\hline & $\begin{array}{c}\text { Sig. } \\
\text { (1-tailed) }\end{array}$ & 0.31 & 0.282 & 0.028 & 0 & 0.256 & & 0.064 & 0.365 \\
\hline & $\mathrm{N}$ & 254 & 254 & 254 & 254 & 254 & 254 & 254 & 254 \\
\hline \multirow{3}{*}{ Wetland } & $\begin{array}{l}\text { Pearson } \\
\text { Correlation }\end{array}$ & $0.106^{*}$ & $0.195^{* *}$ & -0.098 & -0.051 & $-0.115^{*}$ & -0.096 & 1 & $0.203^{* *}$ \\
\hline & $\begin{array}{c}\text { Sig. } \\
\text { (1-tailed) }\end{array}$ & 0.046 & 0.001 & 0.06 & 0.208 & 0.033 & 0.064 & & 0.001 \\
\hline & $\mathrm{N}$ & 254 & 254 & 254 & 254 & 254 & 254 & 254 & 254 \\
\hline \multirow{3}{*}{$\begin{array}{c}\text { Total } \\
\text { Property } \\
\text { Damage }\end{array}$} & $\begin{array}{c}\text { Pearson } \\
\text { Correlation }\end{array}$ & 0.07 & $0.638^{* *}$ & -0.019 & $-0.112^{\star}$ & -0.055 & 0.022 & $0.203^{\star *}$ & 1 \\
\hline & $\begin{array}{c}\text { Sig. } \\
\text { (1-tailed) }\end{array}$ & 0.134 & 0 & 0.382 & 0.038 & 0.19 & 0.365 & 0.001 & \\
\hline & $\mathrm{N}$ & 254 & 254 & 254 & 254 & 254 & 254 & 254 & 254 \\
\hline
\end{tabular}

${ }^{*} \mathrm{p}<0.05 .{ }^{* *} \mathrm{p}<0.01$. Source: The data were produced based on the $1992 \mathrm{NLCD}$ and $2006 \mathrm{NLCD}$, and flood loss data. 
concentrate human populations and things valuable on areas vulnerable to environmental hazards, such as earthquakes, floods, hurricanes, and tornadoes. In addition, city growth definitely needs a situation in which the natural environment should be transformed into a built environment. It is clear that the increase in urban centers denotes the decrease in the pervious land for grass, vegetation, trees, wetlands, and forest. The condition is conducive to flooding simply because the increased impervious land for streets, roads, and structures keeps runoff contained in the urban built-up area after a heavy rainfall for a due course of time until flooding occurs.

As stated in the introduction section, previous studies have been conducted to understand the effect of land use and land cover change on the natural environment and environmental hazards [2] [3] [4] [5] [6]. However, it is notable that almost every research focused on looking at the relationship between landslide and land use/land cover change [3] [15] [16] [17] or between climate effect and land use/land cover change [18] [19]. There has little research done for understanding the effect of land cover change on flooding [5]. That is why this research is thought to contribute to filling the gap in this literature.

The correlation results in this research supported the first hypothesis that the increase in forest area is associated with the increase in the total property damage resulting from flooding. Likewise, the correlation results supported the second hypothesis by showing that the increase in built-up area was statistically associated with the increase in a total property damage resulting from flooding in the state of Texas.

In addition, this research indicates that urbanization leads to a decrease in the spatial extent areas assigned for water-body, forest, and grass, and also lead to an increase in the spatial extent assigned for impervious built-up area, which, in turn, is expected to contribute to flooding. Of course, these research findings don't claim that urbanization is a direct cause of flooding. As a matter of fact, urban flooding can be prevented or the harmful effect can be reduced through a variety of emergency management systems such as emergency preparedness, disaster response and recovery, and hazard mitigation. What is clear through this research is that the research results support the hypotheses suggested above: the condition that forest areas are changed into urban built-up areas can contribute to the likelihood of flood events, which, in turn, claims property losses.

Finally, this research suggests that emergency managers/urban planners and their institutions, non-government organizations, and other stakeholders of emergency management should understand which land use and land cover types in their communities are transformed into built-up areas and accordingly prepare for some hazard mitigation measures against any potential consequence from flooding in order to reduce its harmful impacts.

\section{References}

[1] Federal Emergency Management Agency (1997) The Multi-Hazard Identification and Risk Assessment Report. Federal Emergency Management Agency, Washington 
DC.

[2] Gallardo, M., Gómez, I., Vilar, L., Martínez-Vega, J. and Martín, M.P. (2016) Impacts of Future Land Use/Land Cover on Wildfire Occurrence in the Madrid Region (Spain). Regional Environmental Change, 16, 1047-1061.

https://doi.org/10.1007/s10113-015-0819-9

[3] Persichillo, M.G., Bordoni, M. and Meisina, C. (2017) The Role of Land Use Changes in the Distribution of Shallow Landslides. Science of the Total Environment, 574, 924-937. https://doi.org/10.1016/j.scitotenv.2016.09.125

[4] Liu, J. and Shi, Z.W. (2017) Quantifying Land-Use Change Impacts on the Dynamic Evolution of Flood Vulnerability. Land Use Policy, 65, 198-210. https://doi.org/10.1016/j.landusepol.2017.04.012

[5] Shi, P.-J., Yuan, Y., Zheng, J., Wang, J.-A., Ge, Y. and Qiu, G.-Y. (2007) The Effect of Land Use/Cover Change on Surface Runoff in Shenzhen Region, China, Catena, 69, 31-35. https://doi.org/10.1016/j.catena.2006.04.015

[6] Lepers, E., Lambin, E.F., Janetos, A.C., Defries, R., Achard, F., Ramankutty, N. and Scholes, R.J. (2005) A Synthesis of Information on Rapid Land-Cover Change for the Period 1981-2000. BioScience, 55, 115-124.

https://doi.org/10.1641/0006-3568(2005)055[0115:ASOIOR]2.0.CO;2

[7] Census Bureau (2011) Annual Estimates of the Resident Population for the United States, Regions, States, and Puerto Rico: April 1, 2010 to July 1, 2011. 2011 Population Estimates. United States Census Bureau, Population Division.

[8] US Census Bureau (2010) State and County Quick Facts for Year 2010. http://quickfacts.census.gov/qfd/states/48000.html

[9] Blake, E.S., Rappaport, E.N. and Landsea, C.W. (2007) The Deadliest, Costliest, and Most Intense United States Tropical Cyclones from 1851 to 2006. National Weather Service: National Hurricane Center.

[10] Associated Press (2007) Texas No. 1 Producer of Greenhouse Gases. Associated Press, Dallas Morning News.

[11] Loveland, T.R. and Shaw, D.M. (1996) Multiresolution Land Characterization: Building Collaborative Partnerships. In: Scott, J.M., Tear, T. and Davis, F., Eds., Gap Analysis: A Landscape Approach to Biodiversity Planning, Proceedings of the ASPRS/ GAP Symposium, Charlotte, National Biological Service, Moscow, 83-89.

[12] US Geological Survey. (n.d.) NLCD Classification Schemes.

https://www.mrlc.gov/nlcd92_leg.php

https://www.mrlc.gov/nlcd06_leg.php

[13] Vogelmann, J.E., Sohl, T.L., Campbell, P.V. and Shaw, D.M. (1998) Regional Land Cover Characterization Using Landsat thematic Mapper Data and Ancillary Data Sources. Environmental Monitoring and Assessment, 51, 415-428. https://doi.org/10.1023/A:1005996900217

[14] US Geological Survey (n.d.) 1992 National Land Cover Data. https://www.mrlc.gov/nlcd92_data.php

[15] Alcántara-Ayala, I., Esteban-Chávez, O. and Parrot, J.F. (2005) Landsliding Related to Land-Cover Change: A Diachronic Analysis of Hillslope Instability Distribution in the Sierra Norte, Puebla, Mexico. Catena, 65, 152-165.

[16] Karsli, F., Atasoy, M., Yalcin, A., Reis, S., Demir, O. and Gokceoglu, C. (2009) Effects of Land-Use Changes on Landslides in a Landslide-Prone Area (Ardesen, Rize, NE Turkey). Environmental Monitoring and Assessment, 156, 241-255. https://doi.org/10.1007/s10661-008-0481-5 
[17] Van Beek, L.P.H. and Van Asch, T.W. (2004) Regional Assessment of the Effects of Land-Use Change on Landslide Hazard by Means of Physically Based Modelling. Natural Hazards, 31, 289-304. https://doi.org/10.1023/B:NHAZ.0000020267.39691.39

[18] Bronstert, A., Niehoff, D. and Bürger, G. (2002) Effects of Climate and Land-Use Change on Storm Runoff Generation: Present Knowledge and Modelling Capabilities. Hydrological Processes, 16, 509-529. https://doi.org/10.1002/hyp.326

[19] Gibbard, S., Caldeira, K., Bala, G., Phillips, T.J. and Wickett, M. (2005) Climate Effects of Global Land Cover Change. Geophysical Research Letters, 32, L23705.

Submit or recommend next manuscript to SCIRP and we will provide best service for you:

Accepting pre-submission inquiries through Email, Facebook, LinkedIn, Twitter, etc. A wide selection of journals (inclusive of 9 subjects, more than 200 journals)

Providing 24-hour high-quality service

User-friendly online submission system

Fair and swift peer-review system

Efficient typesetting and proofreading procedure

Display of the result of downloads and visits, as well as the number of cited articles Maximum dissemination of your research work

Submit your manuscript at: http://papersubmission.scirp.org/

Or contact gep@scirp.org 